\title{
INITIATION OF A GLOBALLY NETWORKED PROJECT: A CASE STUDY
}

\author{
Kerttuli Visuri ${ }^{\mathrm{a}}$, Marko Hakonen ${ }^{\mathrm{a}}$, Sari Kela ${ }^{\mathrm{b}}$, Sakari Pihlava ${ }^{\mathrm{a}}$, Casper \\ Lassenius $^{\mathrm{a},}$ Maria Paasivaara ${ }^{\mathrm{a}}$ \\ ${ }^{a}$ Helsinki University of Technology, FINLAND; Email ${ }^{a}$ :first name.last name@hut.fi \\ ${ }^{b}$ TJ Group, FINLAND; Email ${ }^{\text {: }}$ sari-anne.kela@tjgroup.com
}

\begin{abstract}
For networked projects to perform successfully, the initiation of the project is crucial. This case study describes the initiation of one globally networked project performing global software development. A new approach for project initiation is presented. It includes a three stage grouping of the most significant activities belonging to project initiation. The stages include activities emphasizing project proposal, contracting and organizing as well as project kick-off. Applying this three stage model ensures that at least the most important activities will be taken care of during the initiation, which often is carried through without adequate planning and without recognizing the limits of time allocated for the initiating activities.
\end{abstract}

\section{INTRODUCTION}

This paper focuses on initiation of globally networked projects. Such projects have been classified according to the geographical and affiliation dispersion of the project members. Projects, in which the project members are dispersed geographically widely, have been named as distributed projects (Evaristo \& Scudder, 2000). Projects, in which also the affiliation dispersion between the project members is high, have been named as virtual (Katzy et al., 2000) or networked (Paasivaara, 2001) projects.

It has been widely acknowledged that a structured start-up process is an essential part of effective project management (Turner, 1999, Kähkönen, 1999). New product development literature suggests emphasizing management actions in the beginning of projects. Ideas stemming from concurrent engineering as well as iterative and interdependent software development processes also tend to shift the main emphasis from the implementation phases towards project selection, project initiation and iterative and intervening planning phases (Kerzner, 2000). This is especially true, when the network of companies performs project-oriented work and there is a certain amount of geographical and affiliation dispersion between the project members.

Initiation of globally networked projects is still a rather untouched area of research. Initiation of globally networked software development projects - the application area of this study - is also an area, where almost no papers have been published. Most of the research of virtual enterprises performing project-oriented work has focused on selection of cooperation partners, development of infrastructures, mechanisms and tools to support the implementation phases of these projects (Camarinha-Matos \& Afsarmanesh, 1999, Hersleb \& Moitra, 2001). 
Our approach supplements existing knowledge of project and virtual enterprise initiation towards the context of globally networked projects. We propose a definition for the concept 'initiation' and present the key activities of project initiation and the impact of these activities on successful project initiation. The research questions of this paper are:

- How should the initiation of globally networked projects be defined?

- What activities are the most important for successful project initiation?

This paper is structured as follows. Firstly, definitions of the concept 'initiation' are presented. Secondly, the case project is described. After it, we present a three-stage grouping of the initiating activities. Applying this three-stage model in project initiation ensures that at least the most important activities will be taken care of during the initiation of networked projects. The paper closes with concluding remarks and an evaluation of the selected research method.

\section{BACKGROUND AND TERMINOLOGY}

\subsection{Initiation of globally networked projects - definitions and terminology}

In this paper we define the concept initiation starting at a moment when one idea has been selected for further development for a project proposal or, according to Duncan (1996), a project charter. We divide initiation into stages, with which we mean groups of activities forming an integrated entity. Activities are separate tasks, which have to be carried out during the initiation in order to be able to take care of all the necessary planning and preparations relating to the project. The initiation ends when a kick-off meeting has been arranged. End of the kick-off is the starting moment of project implementation.

This definition corresponds with the definition presented by Turner (1999). Turner has named this phase as project design and appraisal. He uses the concept kick-off for the starting moment of project design and appraisal, and a concept project initiation meeting correspondingly as our definition of the kick-off meeting.

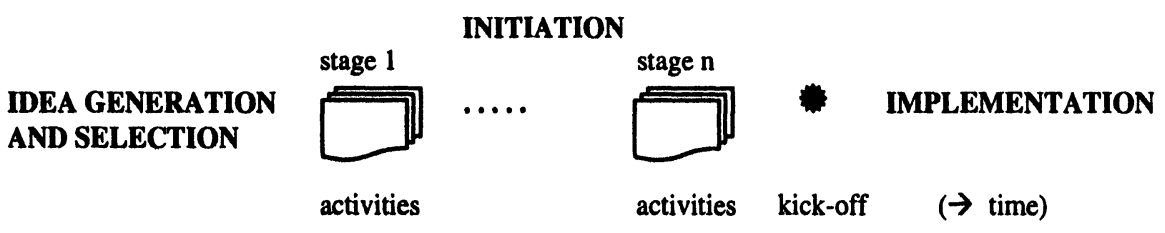

Figure 1 - Project initiation in general; stages, activities and kick-off meeting

\subsection{Project initiating activities in new product development projects}

The life cycle of projects has been studied from many viewpoints. According to Turner (1999) the project design and appraisal includes activities, the target of which is to develop a detailed project model for a final 'implement/do not implement' decision. These activities include a definition of the project product and scope of work at a strategic level. Project organization, quality specifications, time scale, project budget and risk management activities are planned. The main emphasis is on 
evaluation on alternatives and selection of a preferred solution.

Kerzner (2000) uses the concept planning for activities belonging to the project initiation. Planning is a refinement of the conceptual phase, the output of which is a preliminary evaluation and a 'go ahead' decision of the selected idea. The planning phase requires a firm identification of the needed resources, realistic estimates for cost, schedule and performance as well as preparation of all the needed documentation and infrastructure to support the inceptive project. The phase ends in final 'go on/resign' decision before the project implementation.

Hughes \& Cotterel (1999) use the concept planning correspondingly. According to them, planning follows the feasibility study, the output of which is a decision whether the project is worth starting. In software development projects planning is often by nature iterative starting form an outline plan and proceeding towards more detailed plans. More detailed plans will be produced concurrently with the actual development work, that is activities relating to requirements analysis, specifications, design and sometimes also coding of the new software system.

Camarinha-Matos \& Afsarmanesh (1999) have described the creation of globally dispersed production lines and projects. According to them the creation consists of activities relating to partner selection, negotiation and agreements, contract awarding and management as well as tender information. This approach focuses on describing the creation activities instead of defining strictly their chronological sequence.

The terminology is rich and definitions are overlapping. Literature thus suggests several activities for project initiation. They have been gathered into table 1 .

Table 1 - Project initiating activities in previous literature references

\begin{tabular}{|l|l|}
\hline Activities in networked projects & Literature references \\
\hline $\begin{array}{l}\text { Idea generation, prioritisation and idea } \\
\text { selection }\end{array}$ & $\begin{array}{l}\text { Van Aken 2001, Dahan \& Hauser 2000, Kăhkönen } \\
1999\end{array}$ \\
\hline Project proposal, stakeholder interests & Turner 1999, Duncan 1996 \\
\hline Search for and selection of network partners & $\begin{array}{l}\text { Camarinha-Matos \& Afsarmanesh 1999, Humphrey } \\
1990\end{array}$ \\
\hline Goal specification & Turner 1999, Kerzner 2000, Brown 1988 \\
\hline Contracts, intellectual property rights & Kontio et al. 1998, DeMaere 2001 \\
\hline $\begin{array}{l}\text { Project organization nomination, defining } \\
\text { project manager's rights and responsibilities }\end{array}$ & $\begin{array}{l}\text { Turner 1999, Duncan 1996, Lipnack \& Stamps 1999, } \\
\text { Ebert 2001, Kruglianskas \& Thamhain 2000 }\end{array}$ \\
\hline $\begin{array}{l}\text { Meeting of the project members, a kick-off } \\
\text { meeting to facilitate development of trust } \\
\text { and team formation }\end{array}$ & $\begin{array}{l}\text { Brown 1988, Govindarajan \& Gupta 2001, Pabst 1998, } \\
\text { Kruglianskas \& Thamhain 2000, Lipnack \& Stamps } \\
1999, \text { Badiru 1988, Mockus \& Hersleb 2001 }\end{array}$ \\
\hline $\begin{array}{l}\text { Planning and evaluating the product } \\
\text { structure for distributed development }\end{array}$ & $\begin{array}{l}\text { Mockus \& Hersleb 2001, Hersleb \& Moitra 2001, } \\
\text { Ebert 2001, Volters \& Hoogeweegen 1999 }\end{array}$ \\
\hline $\begin{array}{l}\text { Defining common working procedures for } \\
\text { project deliveries, reporting, monitoring, } \\
\text { coordination and communication }\end{array}$ & $\begin{array}{l}\text { Duncan 1996, Camarinha-Matos \& Afsarmanesh 1999, } \\
\text { Badiru 1988, Ebert 2001, Evaristo \& Scudder 2000 }\end{array}$ \\
\hline $\begin{array}{l}\text { Defining common procedures for project } \\
\text { organization cooperation }\end{array}$ & Kokko et al. 2000 \\
\hline
\end{tabular}




\section{CASE AND METHODS}

The case project was a software development project. There were seven juridically separate companies and four nationalities. Work was done simultaneously in three countries. The roles of the companies were: customer, first broker, second broker and four subcontractors. According to VE terminology the roles were correspondingly: VE coordinator, broker (also manager in-/outsourcing), broker, four member enterprises (see: Camarinha-Matos \& Afsarmanesh, 1999, Katzy \& Obozinski, 2000). Later in the text project member refers to any member of the whole project organization, whereas development team member refers to only to those project members, who took part in the actual development work.

The responsibilities of the first broker included project management, technical design and resource management. The second broker was responsible only for providing the human resources. The project organization is depicted in figure 3.

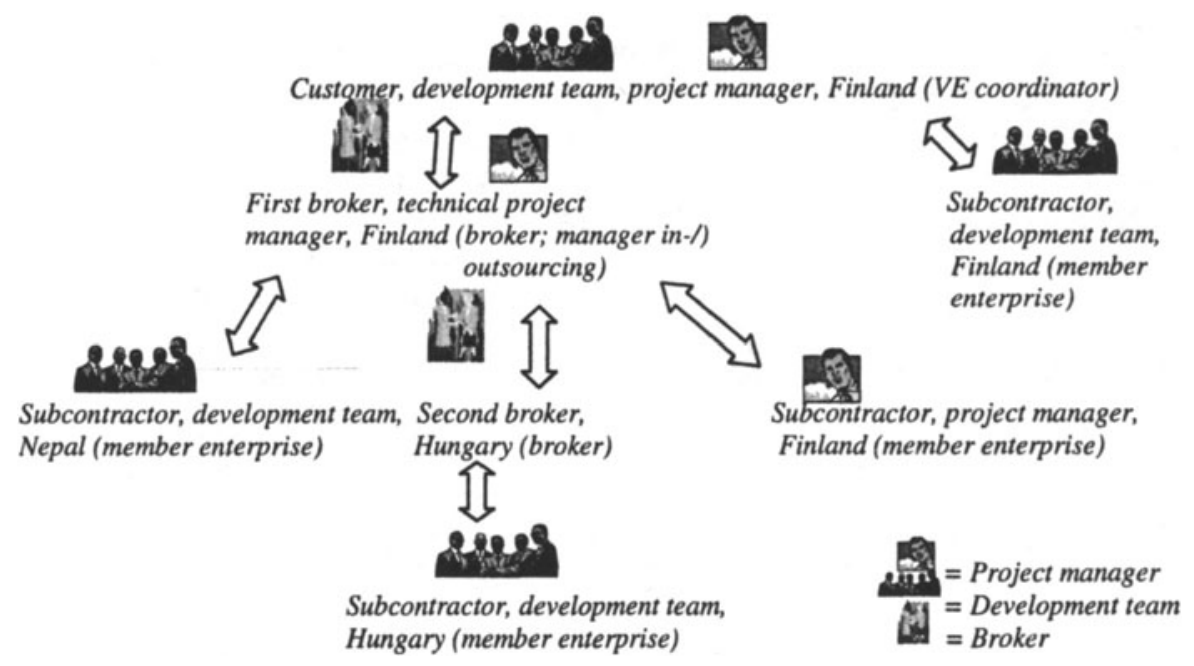

Figure 2 - The case project organization and roles of the participating companies

The case project was selected for presentation for many reasons. The companies had not worked together earlier. Dependencies between product versions made coordination of the work difficult. We found this particularly interesting, because coordination has been found to be one of the key issues of successful implementation of globally networked organizations (Camarinha-Matos \& Afsarmanesh, 1999). Except for one company, the companies were SMEs. It has been visioned (Laubacher \& Malone, 1997), that company networks consisting of SMEs will become common in the $21^{\text {st }}$ century. According to Kähkönen (1999) SMEs have more difficulties in initiating projects in comparison to larger companies. Gaining more knowledge of the initiation of such projects has thus both practical and scientific value.

The sample data followed a case study research (Eisenhardt, 1989). Data was gathered via open-ended interviews. The interviews were carried out during a period of collocated stay, a few weeks after the beginning of this stay. With collocated stay we mean a period of time, during which the development team members of all the 
subcontractors worked physically together. The interviews were tape-recorded and transcribed. Based on the data gathered via the interviews we developed a model for project initiation. The findings were presented to the company representatives in order to get feedback and validation of the results.

The next chapter presents the case project initiation. The activities, which in the interviews were perceived to belong to project initiation, are described. As stated in chapter 2.2, somewhat similar activities have also been named as activities belonging to project planning (e.g. Kerzner, 2000, Hughes \& Cotterel, 1999). Our presentation aims at focusing on initiating activities typical of globally networked projects.

\section{FINDINGS - PROJECT INITIATION ACTIVITIES}

Ten initiation activities are discussed. They have been gathered below.

\author{
Motive clarification \\ Project proposal \\ Goal specification
}

\author{
Partner selection \\ Contracting \\ Architecture evaluation \\ Organization nomination
}

Meeting of the project members Agreeing on working procedures

Rules for cooperation

Figure 3 - Activities of project initiation

\subsection{Stage 1 - Activities relating to project proposal}

Motive clarification. The customer's drivers for establishing a globally networked project instead of an in-house project were lack of suitable human resources, tightness of schedule and expectable savings in development cost. The subcontractors looked for new references and job opportunities. These drivers are common in networked projects and have been reported also by Mockus \& Hersleb (2001).

Project proposal. The customer had no clear project portfolio management policy. Neither projects nor project needs were prioritized in project proposals. Coordination of projects was unsystematic. In our previous project (Rautiainen, 2000) we found out that is often due launching too many projects at a time or not categorizing what type of development projects to launch at a time. This was true in the customer company.

Goal specification. The goal of the project was to develop a new version of an existing software system. The goal was ambiguous and could not be defined precisely. The customer presented the initial requirements specifications. They were specified in discussions with the first broker, but not with the representatives of the other companies. A detailed documented specification of the goal, corresponding to what Hughes \& Cotterel (1999) have proposed, was not produced.

\subsection{Stage 2-Activities relating to contracting and project organizing}

Partner selection. The selection of the first broker was based on previous personal acquaintance of the key representatives of the customer and the first broker. The other project companies, whom the first broker independently selected, were not systematically evaluated. One subcontractor was selected directly by the customer. All companies agreed on starting the work without any trial period. 
Contracting. Work was started with full pace right after a verbal agreement on participating in the project. A legal contract between the customer and the first broker was signed three months after the verbal agreement. It was based on the project plan. Some deliverables could not be specified exactly in the contract text. The contract did not contain supporting mechanisms for project risk management, engouraging incentives for good quality, underlying motives or contract updating procedures. Kontio et al. (1998) has proposed to add such elements into the contract especially if the expected risks are high. Some of them could have been added into the contract. The second broker and the subcontractors also signed contracts with the first broker and/or the customer following the contract between the customer and the first broker.

Architecture evaluation. The case project was launched together with a simultaneously ongoing project. The projects depended on each other's progress in technical and project managerial issues. The technical architecture of the new software had not been planned carefully enough for outsourcing purposes. This resulted coordination difficulties when individual modules were supposed to be tested and built together. Ebert (2001) and Mockus \& Hersleb (2001) have studied various alternatives for task division in software projects and suggested e.g. feature based division, where individual modules can easily be separated. In the case project, this was the objective, but it did not quite succeed and resulted in iterative rounds of feature specification.

Organization nomination. Three project managers were nominated: one representing the customer, one the first broker and one representing the two subcontractors working under the supervision of the first broker. This organizational overlap caused many misunderstandings and difficulties. The customer's organization resembled a weak matrix organization (concept: Duncan, 1996), in which the project manager's authority is limited in relation to functional managers. On the contrary, for example Ebert (2001) has proposed a strong projectized organization for global software projects with a straightforward power of decision for one project manager. This would have made role definition in the remaining parts of the project organization clearer.

\subsection{Stage 3 - Activities relating to project kick-off}

Meeting the project members. The development team members started the work with an introductory course presented by the customer. The course was an educational event (concept: Turner, 1999), but not a kick-off meeting, since the agenda did not contain topics dealing with the coming project, but presentations of the existing old software. Being a face-to face meeting, in which all the development team members participated, the course, however, served as a first possibility of meeting all the project members in person. This has often been reported to be difficult in networked projects for - for example - tight budget or schedule reasons. The introductory course was followed by a period of collocated stay. All the development team members worked physically together for more than one month before scattering back to their home offices. This had clearly many positive impacts on the project team formation and was mentioned in almost every interview. The team members became well acquainted with each other. They learnt to know each other's working habits and expertise areas quickly. They had the opportunity to discuss and refine face-to-face the plans and designs of the new software. All these findings tend to give support to 
earlier findings presented by Lipnack \& Stamps (2000) recommending face-to-face contacts amongst project members of virtual teams.

Agreeing on working procedures. At first, the companies did not agree on common working procedures. Basic project management procedures, such as project reporting, follow-up, change and quality management, as well as explicitly defined development processes, coordination principles, communication rules and product delivery and acceptance procedures were slowly established towards the end of the period of collocated stay. This resulted to weeks of inefficient work until everybody was familiar with the common way of working. Also Ebert et al. (2001) has suggested early establishment of such procedures for increasing transparency of the project.

Rules for cooperation. The circumstances would have been favourable for establishing common rules for teamwork, proposed by Kokko et al. (2000), but like many other working procedures mentioned above, the project members did not discover this possibility early enough.

\section{THREE STAGES OF PROJECT INITIATION}

\section{1 Lessons learned}

The initiation of globally networked projects tends to be underestimated, is more difficult and takes longer than expected. According to Turner (1999) the initiation usually lasts for 1-40 days. The initiation of the case project was expected to last for round one month. Yet, it took three months. $1 / 3$ of the realized project schedule was spent on project initiation.

\begin{tabular}{|l|l|l|}
\hline Estimated duration of initiation & $\bullet$ & 1 month \\
\hline Realized duration of initiation & $\bullet$ & 3 months \\
\hline General duration of initiation & $\bullet-$ & $1-40$ days \\
\hline Total project duration & $\bullet$ & 9 months \\
\hline
\end{tabular}

Figure 4 - Estimated, realized and general duration of project initiation

Two main findings were noticed. Firstly, the project members were ignorant of the duration of the project initiation phase. Secondly, they did not know, which activities should have been taken care of during the initiation. Even if they knew some of them, they did not know the order of importance, recommended sequence or contents of them or - the impacts of leaving some activities out. The time allocated for the initiation fade away. Many questions were still open, when the development team members were supposed to return back to their home countries.

We suggest that the starting and ending moments of the initiation of each globally networked project need thus be more explicitly defined and brought into the knowledge of the all the project members. All of them also need to be familiar with the most significant activities belonging to the initiation, even though they might not all personally participate in all of these activities, like for example contracting. 


\subsection{Three stages of project initiation in globally networked projects}

For improved project initiation management we propose a three stage model consisting of the key initiating activities. The stages focus on project proposal, contracting and organizing as well as project kick-off. The novelty of the model lies on the sequencing and grouping of the selected acitivities applicable for globally networked projects.

The proposed model has several benefits. Adopting a structured project initation process ensures, that at least the most important activities will be taken care of during the initiation. Defining explicitly the starting and ending moments of the initiation phase helps project team members to understand the limits of the initiation phase duration and the importance of taking care of the key activities of project initiation within that time. The proposed model is depicted in figure 5.

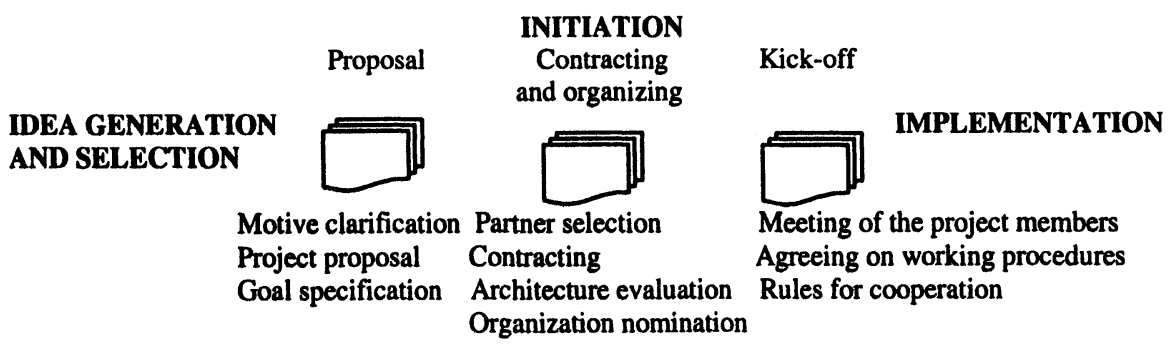

Figure 5 - Project initiation model; proposal, contracting and organizing and kick-off.

Motive clarification, project proposal and goal specification have been grouped into the first stage named as project proposal. Partner selection, contracting, project organization nomination and evaluation of the product architecture form the second stage, named as contracting and organizing. The third stage is named as kick-off. It includes meeting and getting acquainted with all the project members, agreeing on common working procedures and defining common rules for cooperation.

\subsection{Benefits of the proposed project initiation model; comparison to related work}

Stage 1 - Project proposal. Motive clarification of the participating companies, escpecially the customer, is the starting point of the project. A well prepared project proposal is crucial, since work will be outsourced for outside companies, which in turn have to be selected with great care (Camarinha-Matos \& Afsarmanesh, 1999, Humphrey, 1990). Once a globally networked project has been launced out into the project network according to the project proposal, it will often be more costly and difficult to terminate than a corresponding in-house project (Hersleb \& Moitra, 2001).

Stage 2 - Contracting and organizing. Contracting is essential in globally networked projects for two important reasons: for protecting the legal rights of the participating companies (Kontio et al., 1998) and for developing a confidential working climate amongst the companies (DeMaere et al., 2001). Mockus \& Hersleb (2001) have emphasized the importance of early architecture evaluation. It is important to plan beforehand, how it is the possible to divide the work into tasks, to what extent this is 
possible or is it possible at all. Analogous findings have been presented also by Volters \& Hoogeweegen (1999). A clear definition of the role of the project manager improves the performance of a global project (Ebert, 2001). He/she should be ensured enough power to battle for project success between contradictory requirements of various stakeholders and project members from the participating companies.

Stage 3-Meeting the project members. The third stage of the model is named as kick-off emphasizing the utility and importance of early face-to-face contacts in globally networked projects. Yet, meetings amongst all the project members may not be possible at all (Pabst, 1998). The importance of having a change to communicate face-to-face has been reported to have many positive effects: enhancing the evolvement of trust amongst the project members (Lipnack \& Stamps, 2001, Govindarajan \& Gupta, 2001), decreasing misunderstandings (Kruglianskas \& Thamhain, 2000, Pabst, 1998) and having a positive impact on clarifying the common goal (Brown 1988). Agreeing upon and setting up a common development environment including supporting systems for coordination and communication purposes, proposed by Badiru (1988), Mockus \& Hersleb (2001) and Duncan (1996), has been indicated to improve project initiation management. Finally, an explicit agreement on cooperation rules, such as how to behave in conflict situations, has also been reported to enhance performance of development teams (Kokko et al., 2000).

\section{CONCLUDING REMARKS AND FURTHER RESEARCH}

This paper is an output of an ongoing research effort focusing on globally networked software development projects. At this stage, the approach of this paper is descriptive and empirical. The findings presented here base on a multidisciplinary research approach combining engineering, socio-psychological and legal knowledge areas.

The case presented in this paper emphasized two important aspects: the importance of being aware of the time-dependent limits of the project initiation and defining, grouping and prioritising explicitly the key activities belonging to project initiation.

The contributions of this paper are twofold. We made a definition for the concept project initiation applicable to globally networked projects. Secondly, we proposed a three-stage model consisting of a number of activities, according to which the initiation of globally networked projects can be effectively managed. The benefits of each stage and activity were individually presented and evaluated.

The presented results can be deepened with taking into account some limitations of this study. The paper is based on one globally networked project. The presented grouping of the initiating activities can be applied further towards several and different kind of projects. The research method selected for this study - open-ended interviews after the project kick off - can be supplemented by adding additional rounds of interviews or other type of project evaluation questionnaires also after the project completion. These issues have been included in the future research plan.

\section{ACKNOWLEDGEMENTS}

We would like to thank the Finnish National Technology Agency, the cooperating companies and individual project members for their contribution during the research. 


\section{REFERENCES}

1. van Aken, J., Nagel, A. (2001): Organizing the fuzzy front end of new product development. Proc. of the $8^{\text {th }}$ PDMA Conference, Twente.

2. Badiru, A. (1988): Successful initiation of expert system projects. IEEE Transactions on Engineering Management, Vol. 35, No. 3.

3. Brown, R. (1988): Group processes: Dynamics within and between groups. Oxford, Basil Blackwell.

4. Camarinha-Matos, L., Afsarmanesh, H. (1999): Infrastructures for virtual enterprises. Networking industrial enterprises. Kluver Academic Publishers.

5. Dahan, E., Hauser, J. (2000): Managing a dispersed product development process. MIT Sloan School working papers.

6. DeMaere, R., Skulmolski, G., Mohamed, R. Z., Hartman, F. (2001): Contracting and flying the trapeze. Project Management, Vol. 7, No. 1.

7. Duncan, W. (1996): A guide to the project management. Body of knowledge. PMI.

8. Ebert, C., Parro C. H., Suttels, R., Kolarczyk, H. (2001): Improving validation activities in a global software development. Proc. of the $23^{\text {rd }}$ ICSE'01 Conference, Toronto.

9. Eisenhardt, K. (1989): Building theories from case study research. Academy of Management Review, Vol. 14, No. 4.

10. Evaristo, R., Scudder R. (2000): Geographically distributed project teams: A dimensional analysis. Proc. of the $33^{\text {rd }}$ Hawaii International Conference on System Sciences.

11. Govindarajan, V., Gupta, A. (2001): Building an effective global business team. http://mitsloan.mit.edu/smr/reprints.html.

12. Hersleb, J., Moitra, D. (2001): Global software development. IEEE Software, Jan/Feb.

13. Hughes, B., Cotterell, M. (1999): Software project management. McGraw-Hill, Cambridge University Press.

14. Humphrey, W. (1990): Managing the software process. Addison-Wesley.

15. Katzy, B., Evaristo, R., Zigurs, I. (2000): Knowledge management in virtual projects: A research agenda. Proc. of the $33^{\text {rd }}$ Hawaii International Conference on System Sciences.

16. Katzy, B., Obozinski, V. (2000): Designing the virtual enterprise. Proc. of the $2^{\text {nd }}$ Virtual Enterprises Conference, Buenos Aires.

17. Kerzner, H. (2001): Project management. A systems approach to planning, scheduling and controlling. $7^{\text {th }}$ ed. John Wiley \& Sons, NY.

18. Kokko, N., Vartiainen, M., Hakonen, M., Simola, A., Rantamäki, T. (2000): The learning project model. A tool for managing and developing R\&D project work. Proc. of the $7^{\text {th }}$ International Product Development Conference, Leuven, Belgium, May.

19. Kontio, J., Pitkănen, O., Sulonen R. (1998): Toward better software projects and contracts: Commitment specifications in software development projects. Proc. of the $20^{\text {th }}$ ICSE' 98 Conference, Washington, DC.

20. Kruglianskas, I., Thamhain H. (2000): Managing technology-based projects in multinational environments. IEEE Transactions on Engineering Management, Vol. 47, №. 1.

21. Kăhkönen, K. (1999): Multi-character model of the construction project definition process. Automation in Construction, No. 8.

22. Laubacher, R., Malone, T. (1997): Two scenarios of $21^{\text {st }}$ century organizations: Shifting networks of small firms or all-encompassing 'Virtual countries'? MIT Scenario Group, $21^{\text {st }}$ Century Initiative Working Paper Series, No. 1.

23. Lipnack, J., Stamps, J. (2000): Virtual teams. People working across boundaries with technology. John Wiley \& Sons, NY.

24. Mockus, A., Hersleb, J. (2001): Challenges of global software development. Proc. of $7^{\text {th }}$ Int. Software Metrics Symposium, London.

25. Paasivaara, M., Lassenius, C. (2001): Communication in new product development networks. A case study. Proc. of $8^{\text {th }}$ Int. Product Development Management Conference, Twente, Netherlands.

26. Pabst, D. (1998): Inside the looking glass: Cultural diversity in global project teams. Project Management, Vol. 4, No.1.

27. Rautiainen, K., Nissinen, M., Lassenius, C. (2000): Improving multi-project management in two product development organizations. Proc. of the $33^{\text {rd }}$ Hawaii Inter. Conference on System Sciences.

28. Turner, R. (1999): The handbook of project-based management. Improving the processes for achieving strategic objectives. 2. ed. McGraw-Hill, Cambridge University Press.

29. Volters, M., Hoogeweegen, M. (1999): Management support for globally operating virtual organizations: The case of KML distribution. Proc. of the $32^{\text {nd }}$ Hawaii Int. Conf. on System Sciences. 